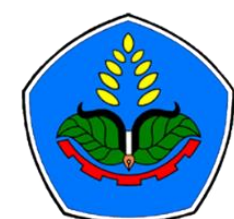

AGROPROSS

National Conference

Proceedings of Agriculture
Proceedings:

Peran Teaching Factory di Perguruan Tinggi Vokasi Dalam Mendukung Ketahanan Pangan Pada Era New Normal

Tempat : Politeknik Negeri Jember

Tanggal : 8-9 Juli 2020

\section{Publisher :}

Agropross, National Conference Proceedings of Agriculture

ISBN : 978-623-94036-6-9

DOI : 10.25047 /agropross.2020.47

\title{
Karakter Fisiologis Benih Kakao (Theobroma cacao L.) Pada Beberapa Kondisi Suhu Dan Media Simpan Yang Berbeda
}

\author{
Author(s): Eva Rosdiana ${ }^{(1)^{*}}$, Ahadiyat Yugi $\mathrm{R}^{(2)}$, Sepdian Luri Asmono ${ }^{(1)}$ \\ (1) Jurusan Produksi Pertanian, Politeknik Negeri Jember \\ (2) Fakultas Pertanian Universitas Jenderal Soedirman \\ * Corresponding author: Eva_rosdiana@polije.ac.id
}

\begin{abstract}
The objectives of this study were to know the appropriate storage temperature for cocoa seed to maintain fisiologis caracters, the appropriate storage media for cocoa seed to maintain fisiologis caracters, and the appropriate temperature and storage media for cocoa seed to maintain fisiologis caracters. This research make a Analysis of varians with multilocation model in a randomized complete block design. Temperatures of storage viz. the room temperature (25-270C), air conditioner temperature (18-200C), refrigerator temperature (13-150C), and seed storage medias viz. sawdust, cocopeat and coconut shell ash were tested. The results showed under room temperature with sawdust media obtained lowest moisture content, lowest DHL, and highest respiration.
\end{abstract}

Keywords:

Cocoa seed;

Fisiologis caracters

Storage;

Media

temperature;

\section{Kata Kunci: ABSTRAK \\ Benih kakao; Penelitian ini bertujuan untuk mengetahui suhu simpan yang sesuai terhadap karakter fisiologis benih kakao, media simpan yang sesuai terhadap karakter fisiologis benih kakao, dan suhu simpan \\ Karakter yang sesuai pada media simpan yang digunakan terhadap karakter fisiologis benih kakao. Penelitian \\ fisiologis; \\ Penyimpanan; dilaksanakan selama tiga bulan dan dianalisis menggunakan analisis sidik ragam model uji multilokasi dengan rancangan kelompok lengkap teracak terdiri atas 2 faktor, suhu penyimpanan terdiri atas tiga: suhu kamar (25-270C), suhu AC (18-200C), suhu refrigerator (13-150C), dan media simpan terdiri atas: serbuk gergaji, serbuk sabut kelapa dan abu tempurung kelapa. Hasil \\ Suhu media; penelitian menunjukkan, penyimpanan pada suhu kamar menggunakan media simpan serbuk gergaji menghasilkan kadar air terendah, DHL terendah dan Laju respirasi tertinggi.}




\section{PENDAHULUAN}

Kakao merupakan salah satu komoditas perkebunan dan berperan penting bagi perekonomian Indonesia, terutama dalam hal sumber pendapatan petani dan devisa Negara, ini merupakan peluang bagi Indonesia untuk terus meningkatkan produksi kakao. Rendahnya produktivitas kakao antara lain disebabkan oleh rendahnya tingkat penggunaan benih dari jenis unggul. Pengadaan benih dari jenis unggul dianggap membutuhkan dana yang cukup besar karena harus memesan dari tempat lain yang sangat jauh, dengan harga benih yang cukup mahal. Selain itu, harus menerima resiko penurunan viabilitas benih atau penurunan mutu fisiologis benih setelah tiba ditangan petani/pemesan (Rachmawati, 2010).

Benih kakao yang tergolong ke dalam benih rekalsitran, mempunyai masa hidup yang singkat dan sukar untuk disimpan lama karena kadar airnya yang tinggi, sehingga laju respirasi meningkat yang juga di tandai dengan meningkatnya kebocoran membran sel, dan benih lebih cepat mengalami kemunduran (deteriorasi). Untuk itu, diperlukan usaha dalam mempertahankan kadar air benih agar laju respirasi berjalan lambat selama dalam penyimpanan dan tidak terjadi kerusakan membran sel. Salah satunya dengan memperhatikan suhu yang sesuai untuk penyimpanan benih kakao, serta media simpan yang digunakan yang mempunyai peranan penting agar benih kakao dapat disimpan dalam jangka waktu yang lama tanpa menurunkan kadar airnya, untuk itu perlu dilakukan penelitian mengenai karakter fisiologis benih kakao pada beberapa kondisi suhu dan media simpan yang berbeda. Penelitian ini bertujuan untuk mengetahui suhu simpan yang sesuai terhadap karakter fisiologis benih kakao, media simpan yang sesuai terhadap karakter fisiologis benih kakao, dan suhu simpan yang sesuai pada media yang digunakan terhadap karakter fisiologis benih kakao.

\section{BAHAN DAN METODE}

Penelitian ini dilaksanakan di Laboratorium Agronomi, Laboratorium Teknologi Pertanian, Laboratorium Kimia Fisik, Laboratorium Pemuliaan Tanaman Fakultas Pertanian dan Screen House di lingkungan Universitas Jenderal Soedirman pada ketinggian tempat $\pm 110 \mathrm{~m}$ dpl.

Penelitian ini menggunakan percobaan multi lokasi menggunakan rancangan kelompok lengkap teracak yang terdiri atas dua faktor yaitu: suhu penyimpanan terdiri atas tiga yaitu $\mathrm{S} 1$ : suhu kamar (25 - 270C), S2: 18 - 200C (suhu AC), S3: $13-150 \mathrm{C}$ (suhu refrigerator), media simpan yang terdiri atas tiga jenis yaitu M1: Serbuk gergaji, M2: Serbuk sabut kelapa, M3: Abu tempurung kelapa. Sembilan unit percobaan diulang empat kali sehingga menghasilkan 36 perlakuan dan pengamatan dilakukan setiap satu minggu sekali selama 5 minggu. Data pengamatan pada setiap suhu dan media simpan dianalisis menggunakan analisis varian dan apabila terdapat beda nyata dilanjutkan dengan uji BNT dengan taraf 5\% (Gomez dan Gomez, 2007). Variabel yang diamati yaitu kadar air benih, DHL (daya hantar listrik) dan laju respirasi.

Penyimpanan benih dilakukan sesuai dengan perlakuan yang akan diberikan. Adapun tahapan-tahapan kegiatan adalah sebagai berikut:

a. Persiapan benih kakao (esktraksi), perendaman dengan fungisida, dikeringanginkan pada suhu kamar.

b. Sterilisasi media simpan menggunakan autoklaf (serbuk gergaji, serbuk sabut kelapa, dan abu tempurung kelapa).

c. Kadar air benih dilakukan pada sebelum dan sesudah penyimpanan. 
d. Benih yang digunakan untuk penelitian dibagi secara acak sesuai dengan perlakuannya, kemudian dimasukkan ke dalam kantong plastik bening berklip dengan ukuran $20 \mathrm{~cm} \mathrm{x}$ $12 \mathrm{~cm}$. Untuk masing-masing perlakuan digunakan 25 butir

e. Serbuk gergaji, serbuk sabut kelapa dan abu tempurung kelapa sebagai media simpan dimasukkan ke dalam wadah penyimpanan. f. Benih diletakkan dalam wadah penyimpanan yang telah diisi dengan media. selanjutnya wadah simpan ditutup dan dimasukkan ke ruang simpan sesuai dengan perlakuan yang diberikan.

\section{HASIL DAN PEMBAHASAN \\ Hasil analisis sidik ragam pengamatan karakter fisiologis benih kakao (Tabel 1).}

Tabel 1. Hasil analisis sidik ragam pengujian karakter fisiologi benih kakao pada beberapa kondisi suhu dan media simpan

\begin{tabular}{cccc}
\hline Variabel & Suhu (S) & Media (M) & Interaksi (SxM) \\
\hline Kadar Air (KA) & tn & tn & tn \\
Minggu 1 penyimpanan & tn & tn & $\mathrm{n}$ \\
Minggu 2 penyimpanan & tn & tn & $\mathrm{n}$ \\
Minggu 3 penyimpanan & tn & tn & $\mathrm{n}$ \\
Minggu 4 penyimpanan & $\mathrm{n}$ & $\mathrm{n}$ & $\mathrm{n}$ \\
Minggu 5 penyimpanan & & & \\
Daya Hantar Listrik (DHL) & $\mathrm{n}$ & $\mathrm{tn}$ & $\mathrm{tn}$ \\
Minggu 1 penyimpanan & $\mathrm{n}$ & $\mathrm{tn}$ & $\mathrm{tn}$ \\
Minggu 2 penyimpanan & $\mathrm{n}$ & $\mathrm{tn}$ & $\mathrm{tn}$ \\
Minggu 3 penyimpanan & $\mathrm{n}$ & $\mathrm{tn}$ & $\mathrm{n}$ \\
Minggu 4 penyimpanan & $\mathrm{n}$ & $\mathrm{n}$ & $\mathrm{n}$ \\
Minggu 5 penyimpanan & & & $\mathrm{tn}$ \\
Laju Respirasi (LR) & $\mathrm{n}$ & $\mathrm{tn}$ & $\mathrm{tn}$ \\
Minggu 1 penyimpanan & $\mathrm{n}$ & $\mathrm{tn}$ & $\mathrm{n}$ \\
Minggu 2 penyimpanan & $\mathrm{n}$ & $\mathrm{n}$ & $\mathrm{n}$ \\
Minggu 3 penyimpanan & $\mathrm{n}$ & $\mathrm{n}$ & $\mathrm{n}$ \\
Minggu 4 penyimpanan & $\mathrm{n}$ & $\mathrm{tn}$ &
\end{tabular}

Keterangan: $n$ ) berbeda nyata pada taraf uji 0,05 , tn) tidak nyata.

\section{Kadar air benih kakao}

Penyimpanan benih kakao pada beberapa kondisi suhu, yaitu suhu kamar (25-270C), suhu AC (18-200C), dan suhu refrigerator (13-150C), menunjukkan perbedaan kadar air yang tidak nyata pada minggu pertama penyimpanan, ditunjukkan pada Gambar 1. Interaksi antara suhu dan media simpan terhadap variabel kadar air pada minggu kedua hingga kelima disajikan pada Tabel 2, Tabel 3, Tabel 4, dan Tabel 5. 


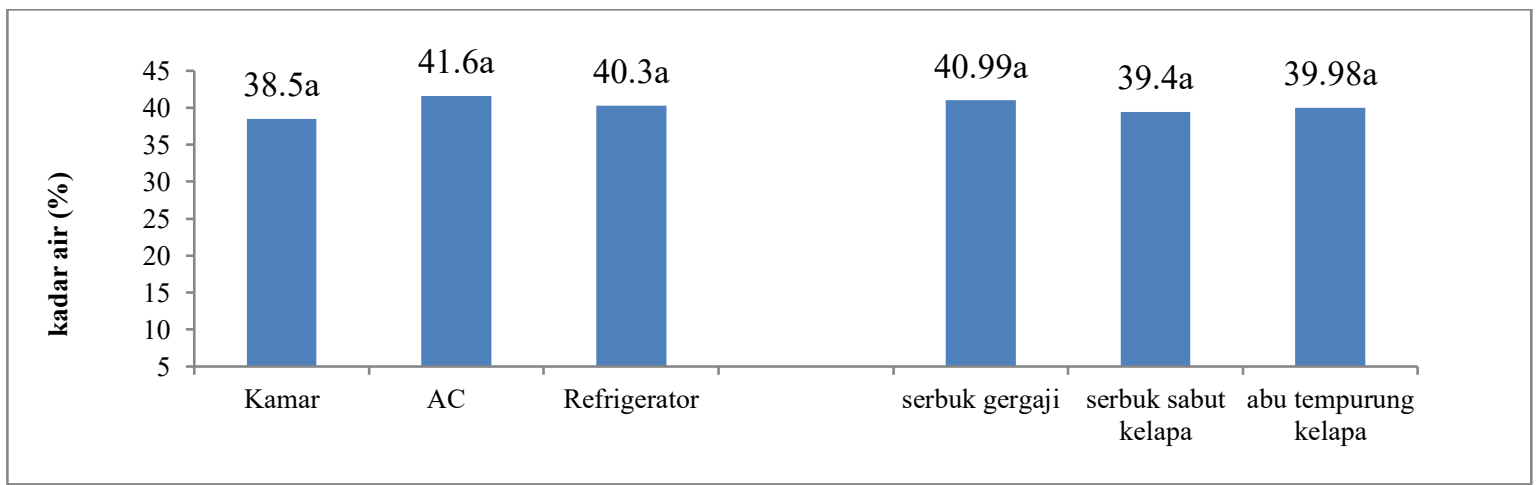

Gambar 1. Persentase kadar air benih kakao pada minggu pertama penyimpanan

Tabel 2. Kadar air benih kakao pada suhu dan media simpan yang berbeda selama penyimpanan minggu ke-2

\begin{tabular}{|c|c|c|c|c|c|c|c|}
\hline \multirow{2}{*}{\multicolumn{2}{|c|}{ Suhu $\left({ }^{0} \mathrm{C}\right)$}} & \multicolumn{6}{|c|}{ Media } \\
\hline & & \multicolumn{2}{|c|}{ Serbuk gergaji } & \multicolumn{2}{|c|}{$\begin{array}{l}\text { Serbuk sabut } \\
\text { kelapa }\end{array}$} & \multicolumn{2}{|c|}{$\begin{array}{c}\text { Abu tempurung } \\
\text { kelapa }\end{array}$} \\
\hline Kamar & $\left(25-27^{0} \mathrm{C}\right)$ & $\begin{array}{c}39,83 \\
\mathrm{~A}\end{array}$ & (a) & $\begin{array}{c}38,75 \text { a } \\
\text { A }\end{array}$ & (a) & $\begin{array}{c}39,25 \text { a } \\
\text { A }\end{array}$ & (a) \\
\hline $\mathrm{AC}$ & $\left(18-20^{\circ} \mathrm{C}\right)$ & $\begin{array}{c}39,65 \\
\mathrm{~A}\end{array}$ & (a) & $\begin{array}{c}39,15 \text { a } \\
\text { A }\end{array}$ & (a) & $\begin{array}{c}37,25 \text { a } \\
\text { A }\end{array}$ & (ab) \\
\hline \multicolumn{2}{|c|}{ Refrigerator $\left(13-15^{\circ} \mathrm{C}\right)$} & $\begin{array}{c}34,75 \mathrm{~b} \\
\mathrm{~B}\end{array}$ & (b) & $\begin{array}{c}37,90 \mathrm{a} \\
\mathrm{B}\end{array}$ & (a) & $\begin{array}{c}39,80 \text { a } \\
\text { A }\end{array}$ & (a) \\
\hline
\end{tabular}

Keterangan:

1. Angka-angka yang diikuti huruf non kapital yang sama pada kolom yang sama (media) menunjukkkan tidak berbeda nyata pada uji BNT pada taraf 5\%

2. Angka-angka yang diikuti huruf kapital yang sama pada baris yang sama (suhu) menunjukkkan tidak berbeda nyata pada uji BNT pada taraf 5\%

3. Angka-angka yang diikuti huruf non kapital yang sama di dalam tanda kurung pada tabel yang sama (media) menunjukkkan tidak berbeda nyata pada uji BNT pada taraf $5 \%$.

Tabel 3. Kadar air benih kakao pada suhu dan media simpan yang berbeda selama penyimpanan minggu ke-3

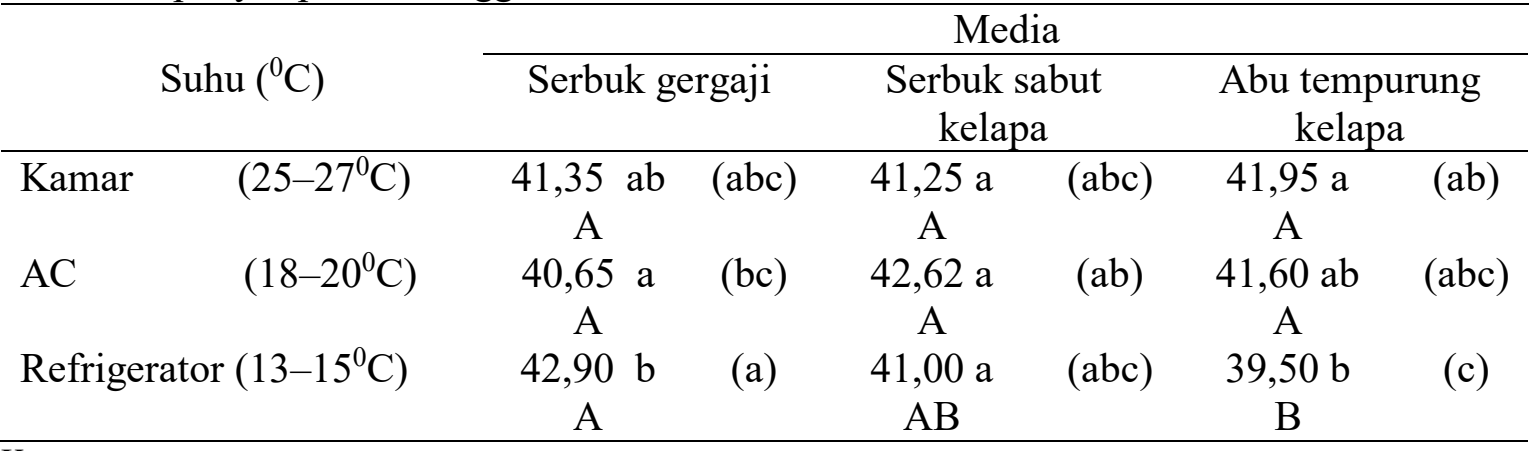

Keterangan:

1. Angka-angka yang diikuti huruf non kapital yang sama pada kolom yang sama (media) menunjukkkan tidak berbeda nyata pada uji BNT pada taraf 5\%

2. Angka-angka yang diikuti huruf kapital yang sama pada baris yang sama (suhu) menunjukkkan tidak berbeda nyata pada uji BNT pada taraf $5 \%$

3. Angka-angka yang diikuti huruf non kapital yang sama di dalam tanda kurung pada tabel yang sama (media) menunjukkkan tidak berbeda nyata pada uji BNT pada taraf 5\%. 
Tabel 4. Kadar air benih kakao pada suhu dan media simpan yang berbeda selama penyimpanan minggu ke-4

\begin{tabular}{|c|c|c|c|c|c|c|c|}
\hline \multirow{2}{*}{\multicolumn{2}{|c|}{ Suhu $\left({ }^{0} \mathrm{C}\right)$}} & \multicolumn{6}{|c|}{ Media } \\
\hline & & \multicolumn{2}{|c|}{ Serbuk gergaji } & \multicolumn{2}{|c|}{$\begin{array}{c}\text { Serbuk sabut } \\
\text { kelapa }\end{array}$} & \multicolumn{2}{|c|}{$\begin{array}{c}\text { Abu tempurung } \\
\text { kelapa }\end{array}$} \\
\hline Kamar & $\left(25-27^{0} \mathrm{C}\right)$ & $\begin{array}{c}41,90 \mathrm{a} \\
\mathrm{A}\end{array}$ & (a) & $\begin{array}{c}42,20 \mathrm{a} \\
\mathrm{A}\end{array}$ & (a) & $\begin{array}{c}41,10 \mathrm{a} \\
\mathrm{A}\end{array}$ & (a) \\
\hline $\mathrm{AC}$ & $\left(18-20^{\circ} \mathrm{C}\right)$ & $\begin{array}{c}41,50 \mathrm{a} \\
\mathrm{A}\end{array}$ & (a) & $\begin{array}{c}37,50 \mathrm{~b} \\
\mathrm{~B}\end{array}$ & (b) & $\begin{array}{c}42,55 \mathrm{a} \\
\mathrm{A}\end{array}$ & (a) \\
\hline \multicolumn{2}{|c|}{ Refrigerator $\left(13-15^{\circ} \mathrm{C}\right)$} & $\begin{array}{c}41,00 \mathrm{a} \\
\mathrm{A}\end{array}$ & (a) & $\begin{array}{c}41,30 \mathrm{a} \\
\mathrm{A}\end{array}$ & (a) & $\begin{array}{c}43,10 \mathrm{a} \\
\mathrm{A}\end{array}$ & (a) \\
\hline
\end{tabular}

Keterangan:

1. Angka-angka yang diikuti huruf non kapital yang sama pada kolom yang sama (media) menunjukkkan tidak berbeda nyata pada uji BNT pada taraf 5\%

2. Angka-angka yang diikuti huruf kapital yang sama pada baris yang sama (suhu) menunjukkkan tidak berbeda nyata pada uji BNT pada taraf $5 \%$

3. Angka-angka yang diikuti huruf non kapital yang sama di dalam tanda kurung pada tabel yang sama (media) menunjukkkan tidak berbeda nyata pada uji BNT pada taraf 5\%.

Tabel 5. Kadar air benih kakao pada suhu dan media simpan yang berbeda selama penyimpanan minggu ke-5

\begin{tabular}{|c|c|c|c|c|c|c|c|}
\hline \multirow{2}{*}{\multicolumn{2}{|c|}{ Suhu $\left({ }^{0} \mathrm{C}\right)$}} & \multicolumn{6}{|c|}{ Media } \\
\hline & & \multicolumn{2}{|c|}{ Serbuk gergaji } & \multicolumn{2}{|c|}{$\begin{array}{c}\text { Serbuk sabut } \\
\text { kelapa }\end{array}$} & \multicolumn{2}{|c|}{$\begin{array}{c}\text { Abu tempurung } \\
\text { kelapa }\end{array}$} \\
\hline Kamar & $\left(25-27^{0} \mathrm{C}\right)$ & $\begin{array}{c}40,02 \mathrm{a} \\
\mathrm{A}\end{array}$ & (a) & $\begin{array}{c}39,60 \mathrm{a} \\
\mathrm{A}\end{array}$ & $(a b)$ & $\begin{array}{c}39,32 \mathrm{a} \\
\mathrm{A}\end{array}$ & $(a b)$ \\
\hline $\mathrm{AC}$ & $\left(18-20^{\circ} \mathrm{C}\right)$ & $\begin{array}{c}39,92 \text { a } \\
\text { A }\end{array}$ & (a) & $\begin{array}{c}36,40 \mathrm{~b} \\
\mathrm{~B}\end{array}$ & (c) & $\begin{array}{c}40,25 \mathrm{a} \\
\mathrm{A}\end{array}$ & (a) \\
\hline \multicolumn{2}{|c|}{ Refrigerator $\left(13-15^{\circ} \mathrm{C}\right)$} & $\begin{array}{c}40,25 \mathrm{a} \\
\mathrm{A}\end{array}$ & (a) & $\begin{array}{c}38,85 \mathrm{a} \\
\mathrm{B}\end{array}$ & (b) & $\begin{array}{c}40,00 \mathrm{a} \\
\mathrm{A}\end{array}$ & (a) \\
\hline
\end{tabular}

Keterangan:

1. Angka-angka yang diikuti huruf non kapital yang sama pada kolom yang sama (media) menunjukkkan tidak berbeda nyata pada uji BNT pada taraf $5 \%$

2. Angka-angka yang diikuti huruf kapital yang sama pada baris yang sama (suhu) menunjukkkan tidak berbeda nyata pada uji BNT pada taraf 5\%

3. Angka-angka yang diikuti huruf non kapital yang sama di dalam tanda kurung pada tabel yang sama (media) menunjukkkan tidak berbeda nyata pada uji BNT pada taraf 5\%.

\section{Daya Hantar Listrik (DHL)}

Pengaruh suhu dan media simpan terhadap daya hantar listrik (DHL) pada penyimpanan minggu pertama, kedua dan ketiga menunjukkan perbedaan yang nyata (Tabel 6). Interaksi antara suhu dan media simpan terdapat pada benih yang disimpan pada minggu keempat dan kelima, hasil selengkapnya disajikan pada Tabel 7 dan 8 .

Tabel 6. Daya Hantar Listrik (DHL) benih kakao selama penyimpanan 1, 2 dan 3 minggu

\begin{tabular}{llccc}
\hline & \multirow{2}{*}{ Suhu $\left({ }^{\circ} \mathrm{C}\right)$} & \multicolumn{3}{c}{ Lama penyimpanan (minggu) } \\
\cline { 3 - 5 } & & 1 & 2 & 3 \\
\hline Kamar & $\left(25-27{ }^{0} \mathrm{C}\right)$ & $0,69 \mathrm{~b}$ & $0,62 \mathrm{~b}$ & $0,90 \mathrm{~b}$ \\
AC & $\left(18-20{ }^{\circ} \mathrm{C}\right)$ & $0,64 \mathrm{~b}$ & $0,71 \mathrm{~b}$ & $0,67 \mathrm{~b}$
\end{tabular}




\begin{tabular}{lccc} 
Refrigerator $\left(13-15^{\circ} \mathrm{C}\right)$ & $0,86 \mathrm{a}$ & $1,59 \mathrm{a}$ & $4,45 \mathrm{a}$ \\
\hline \multicolumn{1}{c}{ Media simpan } & & & \\
\hline Serbuk gergaji & $0,73 \mathrm{~b}$ & $1,05 \mathrm{a}$ & $1,97 \mathrm{ab}$ \\
Serbuk sabut kelapa & $0,76 \mathrm{~b}$ & $0,95 \mathrm{a}$ & $2,17 \mathrm{a}$ \\
Abu tempurung kelapa & $0,69 \mathrm{a}$ & $0,93 \mathrm{a}$ & $1,88 \mathrm{~b}$ \\
\hline $\mathrm{CV}$ & 7,28 & 8,83 & 7,09 \\
\hline
\end{tabular}

Keterangan:

1. Sebelum dianalisis data telah ditransformasikan ke dalam bentuk $(x+0,5) 1 / 2$

2. Angka-angka yang diikuti oleh huruf yang sama pada kolom yang sama menunjukkkan tidak berbeda nyata menurut uji BNT $\alpha=5 \%$ setelah ditransformasi.

Tabel 7. DHL benih kakao pada suhu dan media simpan yang berbeda selama penyimpanan minggu ke-4

\begin{tabular}{|c|c|c|c|c|c|c|}
\hline \multirow[b]{2}{*}{ Suhu $\left({ }^{0} \mathrm{C}\right)$} & \multicolumn{6}{|c|}{ Media } \\
\hline & \multicolumn{2}{|c|}{ Serbuk gergaji } & \multicolumn{2}{|c|}{$\begin{array}{c}\text { Serbuk sabut } \\
\text { kelapa }\end{array}$} & \multicolumn{2}{|c|}{$\begin{array}{c}\text { Abu tempurung } \\
\text { kelapa }\end{array}$} \\
\hline$\left(25-27^{0} \mathrm{C}\right)$ & $\begin{array}{c}0,99 \mathrm{a} \\
\mathrm{B}\end{array}$ & (d) & $\begin{array}{c}1,56 \mathrm{a} \\
\mathrm{A}\end{array}$ & (c) & $\begin{array}{c}1,12 \mathrm{a} \\
\mathrm{AB}\end{array}$ & $(\mathrm{cd})$ \\
\hline$\left(18-20^{0} \mathrm{C}\right)$ & $\begin{array}{c}1,02 \mathrm{a} \\
\mathrm{A}\end{array}$ & (cd) & $\begin{array}{c}1,03 \mathrm{a} \\
\mathrm{A}\end{array}$ & (cd) & $\begin{array}{c}0,84 \mathrm{a} \\
\mathrm{A}\end{array}$ & (d) \\
\hline Refrigerator $\left(13-15^{\circ} \mathrm{C}\right)$ & $\begin{array}{c}4,19 \mathrm{~b} \\
\mathrm{~B}\end{array}$ & (b) & $\begin{array}{c}3,92 \mathrm{~b} \\
\mathrm{~B}\end{array}$ & (b) & $\begin{array}{c}5,25 \mathrm{~b} \\
\mathrm{~A}\end{array}$ & (a) \\
\hline
\end{tabular}

Keterangan:

1. Angka-angka yang diikuti huruf non kapital yang sama pada kolom yang sama (media) menunjukkkan tidak berbeda nyata pada uji BNT pada taraf $5 \%$

2. Angka-angka yang diikuti huruf kapital yang sama pada baris yang sama (suhu) menunjukkkan tidak berbeda nyata pada uji BNT pada taraf $5 \%$

3. Angka-angka yang diikuti huruf non kapital yang sama di dalam tanda kurung pada tabel yang sama (media) menunjukkkan tidak berbeda nyata pada uji BNT pada taraf $5 \%$.

Tabel 8. DHL benih kakao pada suhu dan media simpan yang berbeda selama penyimpanan minggu ke-5

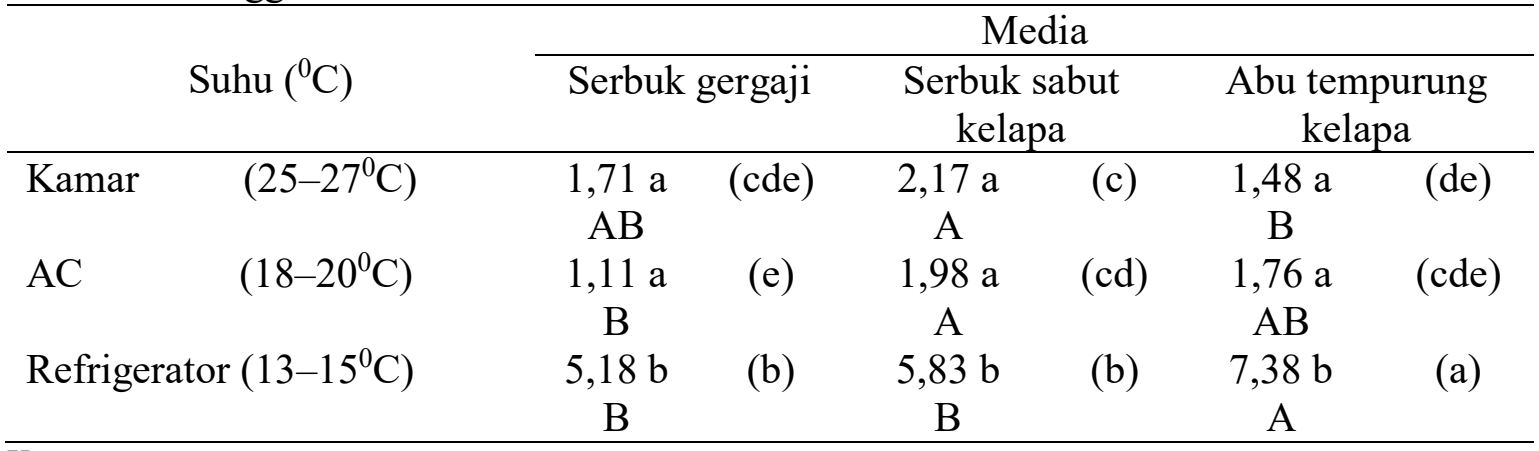

Keterangan:

1. Angka-angka yang diikuti huruf non kapital yang sama pada kolom yang sama (media) menunjukkkan tidak berbeda nyata pada uji BNT pada taraf 5\%

2. Angka-angka yang diikuti huruf kapital yang sama pada baris yang sama (suhu) menunjukkkan tidak berbeda nyata pada uji BNT pada taraf $5 \%$

3. Angka-angka yang diikuti huruf non kapital yang sama di dalam tanda kurung pada tabel yang sama (media) menunjukkkan tidak berbeda nyata pada uji BNT pada taraf 5\%. 


\section{Laju Respirasi (LR)}

Hasil pengamatan terhadap laju respirasi benih untuk suhu kamar dan suhu AC minggu pertama dan kedua menunjukkan perbedaan yang tidak nyata namun berbeda nyata pada suhu refrigerator. Sedangkan media simpan menunjukkan tidak berbeda nyata pada penyimpanan minggu pertama dan kedua pada semua perlakuan media simpan (serbuk gergaji, serbuk sabut kelapa dan abu tempurung kelapa). Selengkapnya disajikan pada Tabel 9. Interaksi antara perlakuan suhu dan media simpan terdapat pada benih yang disimpan pada minggu ketiga hingga kelima penyimpanan, hasil pengamatan selengkapnya disajikan pada Tabel 10, Tabel 11 dan Tabel 12.

Tabel 9. Laju Respirasi (LR) benih kakao selama penyimpanan 1 dan 2 minggu

\begin{tabular}{|c|c|c|}
\hline \multirow{2}{*}{ Suhu $\left({ }^{0} \mathrm{C}\right)$} & \multicolumn{2}{|c|}{ Lama penyimpanan (minggu) } \\
\hline & 1 & 2 \\
\hline$\left(25-27{ }^{0} \mathrm{C}\right)$ & $0,69 \mathrm{a}$ & $0,57 \mathrm{a}$ \\
\hline$\left(18-20{ }^{0} \mathrm{C}\right)$ & $0,67 \mathrm{a}$ & $0,59 \mathrm{a}$ \\
\hline Refrigerator $\left(13-15{ }^{0} \mathrm{C}\right)$ & $0,48 \mathrm{~b}$ & $0,43 \mathrm{~b}$ \\
\hline \multicolumn{3}{|l|}{ Media simpan } \\
\hline Serbuk gergaji & $0,63 \mathrm{a}$ & $0,52 \mathrm{a}$ \\
\hline Serbuk sabut kelapa & $0,61 \mathrm{a}$ & $0,53 \mathrm{a}$ \\
\hline Abu tempurung kelapa & $0,61 \mathrm{a}$ & $0,53 \mathrm{a}$ \\
\hline $\mathrm{CV}$ & 6,67 & 9,86 \\
\hline
\end{tabular}

Keterangan:

1. Sebelum dianalisis data telah ditransformasikan ke dalam bentuk $(x+0,5)^{1 / 2}$

2. Angka-angka yang diikuti oleh huruf yang sama pada kolom yang sama menunjukkkan tidak berbeda nyata menurut uji BNT $\alpha=5 \%$ setelah ditransformasi.

Tabel 10. Laju respirasi benih kakao pada suhu dan media simpan yang berbeda selama penyimpanan minggu ke-3

\begin{tabular}{|c|c|c|c|c|c|c|c|}
\hline \multirow{2}{*}{\multicolumn{2}{|c|}{ Suhu $\left({ }^{0} \mathrm{C}\right)$}} & \multicolumn{6}{|c|}{ Media } \\
\hline & & \multicolumn{2}{|c|}{ Serbuk gergaji } & \multicolumn{2}{|c|}{$\begin{array}{c}\text { Serbuk sabut } \\
\text { kelapa }\end{array}$} & \multicolumn{2}{|c|}{$\begin{array}{l}\text { Abu tempurung } \\
\text { kelapa }\end{array}$} \\
\hline Kamar & $\left(25-27^{0} \mathrm{C}\right)$ & $\begin{array}{c}0,64 \mathrm{a} \\
\mathrm{B}\end{array}$ & (c) & $\begin{array}{c}0,71 \mathrm{a} \\
\mathrm{A}\end{array}$ & $(a b)$ & $\begin{array}{c}0,72 \mathrm{a} \\
\mathrm{A}\end{array}$ & $(a b)$ \\
\hline $\mathrm{AC}$ & $\left(18-20^{\circ} \mathrm{C}\right)$ & $\begin{array}{c}0,76 \mathrm{~b} \\
\mathrm{~A}\end{array}$ & (a) & $\begin{array}{c}0,66 \mathrm{a} \\
\mathrm{B}\end{array}$ & (bc) & $\begin{array}{c}0,66 \mathrm{a} \\
\mathrm{B}\end{array}$ & (bc) \\
\hline \multicolumn{2}{|c|}{ Refrigerator $\left(13-15^{\circ} \mathrm{C}\right)$} & $\begin{array}{c}0,49 \mathrm{c} \\
\mathrm{A}\end{array}$ & (d) & $\begin{array}{c}0,37 \mathrm{~b} \\
\mathrm{~B}\end{array}$ & (e) & $\begin{array}{c}0,29 \mathrm{~b} \\
\mathrm{C}\end{array}$ & (f) \\
\hline
\end{tabular}

Keterangan:

1. Angka-angka yang diikuti huruf non kapital yang sama pada kolom yang sama (media) menunjukkkan tidak berbeda nyata pada uji BNT pada taraf 5\%

2. Angka-angka yang diikuti huruf kapital yang sama pada baris yang sama (suhu) menunjukkkan tidak berbeda nyata pada uji BNT pada taraf $5 \%$

3. Angka-angka yang diikuti huruf non kapital yang sama di dalam tanda kurung pada tabel yang sama (media) menunjukkkan tidak berbeda nyata pada uji BNT pada taraf 5\%. 
Tabel 11. Laju respirasi benih kakao pada suhu dan media simpan yang berbeda selama penyimpanan minggu ke-4

\begin{tabular}{|c|c|c|c|c|c|c|}
\hline \multirow[b]{2}{*}{ Suhu $\left({ }^{0} \mathrm{C}\right)$} & \multicolumn{6}{|c|}{ Media } \\
\hline & \multicolumn{2}{|c|}{ Serbuk gergaji } & \multicolumn{2}{|c|}{$\begin{array}{c}\text { Serbuk sabut } \\
\text { kelapa }\end{array}$} & \multicolumn{2}{|c|}{$\begin{array}{c}\text { Abu tempurung } \\
\text { kelapa }\end{array}$} \\
\hline$\left(25-27^{0} \mathrm{C}\right)$ & $\begin{array}{c}0,41 \mathrm{a} \\
\mathrm{A}\end{array}$ & (a) & $\begin{array}{c}0,42 \mathrm{a} \\
\mathrm{A}\end{array}$ & (a) & $\begin{array}{c}0,38 \mathrm{a} \\
\mathrm{A}\end{array}$ & $(\mathrm{ab})$ \\
\hline$\left(18-20^{0} \mathrm{C}\right)$ & $\begin{array}{c}0,28 \mathrm{~b} \\
\mathrm{~A}\end{array}$ & $(\mathrm{cde})$ & $\begin{array}{c}0,35 \mathrm{a} \\
\mathrm{A}\end{array}$ & $(a b c)$ & $\begin{array}{c}0,13 \mathrm{~b} \\
\mathrm{~B}\end{array}$ & (f) \\
\hline Refrigerator $\left(13-15^{\circ} \mathrm{C}\right)$ & $\begin{array}{c}0,32 \mathrm{~b} \\
\mathrm{~A}\end{array}$ & (bcd) & $\begin{array}{c}0,19 \mathrm{~b} \\
\mathrm{~B}\end{array}$ & (ef) & $\begin{array}{c}0,24 \mathrm{c} \\
\mathrm{AB}\end{array}$ & (de) \\
\hline
\end{tabular}

Keterangan:

1. Angka-angka yang diikuti huruf non kapital yang sama pada kolom yang sama (media) menunjukkkan tidak berbeda nyata pada uji BNT pada taraf $5 \%$

2. Angka-angka yang diikuti huruf kapital yang sama pada baris yang sama (suhu) menunjukkkan tidak berbeda nyata pada uji BNT pada taraf 5\%

3. Angka-angka yang diikuti huruf non kapital yang sama di dalam tanda kurung pada tabel yang sama (media) menunjukkkan tidak berbeda nyata pada uji BNT pada taraf 5\%.

Tabel 12. Laju respirasi benih kakao pada suhu dan media simpan yang berbeda selama penyimpanan minggu ke-5

\begin{tabular}{|c|c|c|c|c|c|c|c|}
\hline \multirow{2}{*}{\multicolumn{2}{|c|}{ Suhu $\left({ }^{0} \mathrm{C}\right)$}} & \multicolumn{6}{|c|}{ Media } \\
\hline & & \multicolumn{2}{|c|}{ Serbuk gergaji } & \multicolumn{2}{|c|}{$\begin{array}{l}\text { Serbuk sabut } \\
\text { kelapa }\end{array}$} & \multicolumn{2}{|c|}{$\begin{array}{l}\text { Abu tempurung } \\
\text { kelapa }\end{array}$} \\
\hline Kamar & $\left(25-27^{0} \mathrm{C}\right)$ & $\begin{array}{c}0,37 \mathrm{a} \\
\mathrm{A}\end{array}$ & (a) & $\begin{array}{c}0,37 \mathrm{a} \\
\mathrm{A}\end{array}$ & (a) & $\begin{array}{c}0,38 \mathrm{a} \\
\mathrm{A}\end{array}$ & (a) \\
\hline $\mathrm{AC}$ & $\left(18-20^{\circ} \mathrm{C}\right)$ & $\begin{array}{c}0,30 \mathrm{~b} \\
\mathrm{~A}\end{array}$ & (b) & $\begin{array}{c}0,32 \mathrm{a} \\
\mathrm{A}\end{array}$ & $(a b)$ & $\begin{array}{c}0,20 \mathrm{~b} \\
\mathrm{~B}\end{array}$ & (c) \\
\hline \multicolumn{2}{|c|}{ Refrigerator $\left(13-15^{\circ} \mathrm{C}\right)$} & $\begin{array}{c}0,19 \mathrm{c} \\
\mathrm{AB}\end{array}$ & (cd) & $\begin{array}{c}0,12 \mathrm{c} \\
\mathrm{B}\end{array}$ & $(d)$ & $\begin{array}{c}0,22 \mathrm{~b} \\
\mathrm{~A}\end{array}$ & (c) \\
\hline
\end{tabular}

Keterangan:

1. Angka-angka yang diikuti huruf non kapital yang sama pada kolom yang sama (media) menunjukkkan tidak berbeda nyata pada uji BNT pada taraf $5 \%$

2. Angka-angka yang diikuti huruf kapital yang sama pada baris yang sama (suhu) menunjukkkan tidak berbeda nyata pada uji BNT pada taraf 5\%

3. Angka-angka yang diikuti huruf non kapital yang sama di dalam tanda kurung pada tabel yang sama (media) menunjukkkan tidak berbeda nyata pada uji BNT pada taraf 5\%.

Benih kakao yang disimpan pada suhu kamar dengan menggunakan media simpan serbuk gergaji pada minggu kedua menunjukkan kadar air tertinggi, dan terendah pada suhu refrigerator menggunakan media simpan serbuk gergaji (Tabel 2). Hal ini disebabkan oleh adanya perubahan suhu kamar yang fluktuatif dan kelembaban media serbuk gergaji yang relatif lebih tinggi dibandingkan media simpan lainnya. Berdasarkan hasil penelitian Purnomohadi
(1982), pada kondisi penyimpanan suhu kamar, absorpsi air dari serbuk gergaji sebagai media simpan lebih tinggi dibandingkan suhu AC. Kelembaban lingkungan simpan dapat berpengaruh langsung terhadap kadar air benihnya (Delouche, 1977).

Pada penyimpanan minggu kedua, suhu kamar dan suhu AC menunjukkan nilai DHL tidak berbeda, namun pada suhu refrigerator nilai DHL semakin meningkat (Tabel 6). Ini disebabkan, pada suhu 
refrigerator laju respirasi masih berjalan lambat sehingga cadangan makanan yang terdapat dalam benih untuk proses metabolisme selama dalam penyimpanan masih mencukupi proses perkecambahan, yang akan dilanjutkan pada proses pertumbuhan bibit. Menurut Rahayu (2002), benih yang cepat muncul cenderung memiliki kecepatan tumbuh yang tinggi. Kecepatan tumbuh yang tinggi tersebut dikarenakan, benih dalam penyimpanan dapat mempertahankan cadangan makanan, dan bisa menekan perombakan akibat proses respirasi, sehingga pada saat dikecambahkan memiliki energi yang besar untuk cepat muncul hingga membentuk organ-organ tanaman yang lain. Berdasarkan hasil penelitian Asrayanti (2007) mengatakan bahwa lama penyimpanan dan temperatur berpengaruh menurunkan laju respirasi benih kakao setelah dua minggu penyimpanan pada temperatur $8,5-10^{\circ} \mathrm{C}$ dan $27-30^{\circ} \mathrm{C}$ hingga akhir pengamatan.

Pada saat memasuki minggu ketiga, kadar air benih yang disimpan pada suhu refrigerator menggunakan media simpan serbuk gergaji lebih tinggi, dibandingkan suhu kamar dan suhu AC pada media simpan apapun (Tabel 3), hal ini juga sejalan dengan nilai DHL yang semakin meningkat (Tabel 6) pada suhu refrigerator, ini disebabkan oleh penyimpanan suhu refrigerator cenderung lebih stabil dibandingkan suhu lainnya, juga kelembaban media serbuk gergaji yang relatif lebih tinggi (50\%), sehingga kadar air menjadi meningkat, karena benih kakao tidak toleran terhadap suhu rendah dan kadar air yang terlalu tinggi,.

Menurut Cahairani (1991), kadar air yang tinggi akan menyebabkan terjadinya respirasi yang lebih cepat, perubahan karbohidrat menjadi lemak selanjutnya membentuk asam lemak bebas, serta perubahan molekul-molekul sukrosa menjadi glukosa. Suhu dan media sangat mempengaruhi laju respirasi benih kakao yang disimpan selama 5 minggu dimana semakin lama benih kakao disimpan laju respirasinya semakin rendah dan bervariasi.

Pada penyimpanan minggu ketiga laju respirasi pada suhu kamar dan suhu AC yang diberikan media simpan apapun menunjukkan nilai yang hampir sama namun laju respirasi tertinggi terdapat pada suhu AC menggunakan media simpan serbuk gergaji sedangkan pada suhu kamar menggunakan media abu tempurung kelapa dan terendah pada suhu refrigerator menggunakan media serbuk sabut kelapa. Ini diduga karena pada suhu refrigerator laju respirasi yang terjadi pada benih kakao semakin cepat sehingga cadangan makanan semakin lama semakin berkurang dan mengakibatkan benih mengalami kemunduran, diketahui juga bahwa pada biji rekalsitran tidak tahan terhadap kekeringan, peka terhadap perlakuan suhu dan kelembaban rendah, serta tidak dapat disimpan lama (Bewley dan Black, 1982).

Suhu udara dapat mempengaruhi proses biokimia maupun organisme lainnya untuk aktif. Proses biokimia serta aktifitas serangga, jamur dan bakteri dapat terhambat pada kondisi suhu dibawah 8$15^{\circ} \mathrm{C}$. Pada kondisi demikian dapat mengakibatkan kerja enzim yang terkandung didalam benih dalam fase istirahat, sehingga dengan demikian baik enzim yang terdapat didalam benih, serangga, jamur maupun bakteri tidak aktif.

Secara normal kadar oksigen di udara sebesar 20\%, jika kadar oksigen lebih rendah, maka laju respirasi benih dapat ditekan. Laju respirasi benih yang tinggi dapat mendegradasi cadangan makanan seperti karbohidrat, protein, dan lemak (Munandar et al. 2004). Penurunan kadar oksigen hingga di bawah batas kritisnya,

dapat memacu terjadinya respirasi anaerobik yang menghasilkan alkohol dan 
mempercepat kemunduran benih (Wills et al. 1981; Munandar \& Rahardjo 2003).

Penyimpanan minggu keempat dan kelima menunjukkan persentase kadar air benih dan nilai DHL meningkat pada suhu refrigerator yang diberi media simpan abu tempurung kelapa (Tabel 7 dan Tabel 8). Hal ini disebabkan, terjadi peningkatan kebocoran benih yang tinggi pada suhu refrigerator dibandingkan suhu kamar dan suhu AC, juga perubahan permeabilitas selaput benih dan perubahan integritas membran (Daniel et al., 2009). Media simpan yang diberikan, juga tidak dapat mengontrol laju kemunduran benih dan mengakibatkan kerusakan terjadi pada membran sel, karena bahan yang dikandung dalam media tersebut sudah tidak berfungsi secara maksimal untuk memperlambat laju respirasi selama penyimpanan, sehingga berdampak pada semakin rendahnya viabilitas dan vigor benih. Nautiyal dan Purahit (1985) menyatakan, kerusakan yang terjadi pada membran sel akan mengakibatkan terjadinya kebocoran metabolit seperti gula, fosfat dan kalium, hal ini berdampak terhadap viabilitas benih.

\section{KESIMPULAN}

1. Suhu kamar (25-27oC) merupakan suhu yang sesuai terhadap karakter fisiologis benih kakao pada minggu ketiga penyimpanan, menghasilkan DHL $0,67 \mathrm{mS} / \mathrm{m}$.

2. Media simpan abu tempurung kelapa merupakan media simpan yang sesuai terhadap karakter fisiologis benih kakao hingga minggu ketiga penyimpanan, menghasilkan DHL $1,88 \mathrm{mS} / \mathrm{m}$.

3. Hingga minggu kelima penyimpanan, suhu kamar menggunakan media abu tempurung kelapa, menghasilkan kadar air terendah 39,32\%, DHL terendah $1,48 \mathrm{mS} / \mathrm{m}$ dan laju respirasi tertinggi $0,38 \mathrm{mg} \mathrm{CO} 2 / \mathrm{g} / \mathrm{jam}$.

\section{DAFTAR PUSTAKA}

Arisandi, D. 2007. Tingkat Keberhasilan dan Pertumbuhan Okulasi Kakao pada Penempelan Mata Tunas dan Umur Batang Bawah yang Berbeda. Skripsi. Jurusan Budidaya Pertanian. Fakultas Pertanian. Universitas Hasanuddin. Makassar.

Baharudin, Satriyas, I.M.R,. Suhartanto, A. Purwantara. 2010. Pengaruh lama penyimpanan dan perlakuan benih terhadap peningkatan vigor benih kakao hibrida, Jurnal Pengkajian dan Pengembangan Teknologi Pertanian. Vol. 13 (1): $73-84$.

Cahairani, M. 1991. Pengaruh Penyimpanan dan Pengupasan Terhadap Daya Kecambah Benih Kelapa Sawit. Buletin Perkebunan. 22(1) : $21-32$.

Daniel, I.Y., E. Adelina dan Maemunah. 2009. Vigor Benih Kakao (Theobroma cacao L.) Pada Berbagai Lama Penyimpanan dan Invigorasi. Jurnal Agroland. 16 (3): 206-212.

Delouche, J.C. 1977. Precepts of seed storage. Seed Technology Laboratory Agronomy Departement. M. S. U. 22.

Gomez, K.A. dan A.A. Gomez. 2007. Prosedur Statistik Untuk Penelitian Pertanian. Edisi kedua. Universitas Indonesia Press. Jakarta. Hal 698.

Justice, O.L. dan L.N., Bass, 2002. Prinsip dan Praktek Penyimpanan Benih (terjemahan) cetakan ke-3. PT. Raja Grafindo Persada, Jakarta. 387 Hal.

Kusmana, C., M. Kalingga dan D. Syamsuwida. 2011. Pengaruh Media Simpan, Ruang Simpan, dan Lama 
Penyimpanan terhadap Viabilitas Benih Rhizophora stylosa Griff. Jurnal Silvikultur Tropika, vol. 03. Hal. 82 - 87.

Nautiyal, A.R., and A.N., Purahit. 1985. Seed Viability in Sal III. Membran Distruption In Ageing Seeds of Shorea Robusta. Seed Science and Technology. 13 (1) : $77-82$.

Purnomohadi. $1982 . \quad$ Pengaruh Kelembaban Serbuk Gergaji Sebagai Media Simpan, Suhu dan Periode Simpan Terhadap Viabilitas Benih Coklat (Theobroma cacao. L). Buletin Agro. Vol XVII. No. I. 10.

Rachmawati, H. 2010. Keragaan dan Mutu Fisiologis Benih Rekalsitran Kakao (Theobroma cacao L.) Pada Berbagai Kondisi Penyimpanan Keragaan dan Mutu Fisiologis Benih Rekalsitran Kakao (Theobrema cacao L.) Pada Berbagai Kondisi Penyimpanan. Fakultas Pertanian, Unhalu. Hal 9.

Rahayu, AY. 2002. Efek Penggunaan Kapur Tohor dan Jenis Kemasan pada Penyimpanan Benih Terhadap Viabilitas dan Vigor Benih Kedelai (Glycine max L. Merril). Universitas Jenderal Soedirman. 3/XXVII P. 112.

Sahupala, A. 2010. Pengaruh suhu dan penyimpanan terhadap viabilitas benih merbau (Intsia bijuga,OK). Jurnal Agroforesti. Vol. v. No. 4. 7.

Sutopo, L. 2004. Teknologi Benih (Edisi Revisi). PT. Raja Grafindo Persada: Jakarta. 155 hal. 